\title{
APPLICATION OF AEROMAGNETICS AS A BASIN DEPTH DISCRIMINATING TOOL PRIOR TO SEISMIC EXPLORATION: A CASE STUDY OF CENTRAL NIGER DELTA, NIGERIA
}

S. E. LEBO AND D. A. OBI

(Received 13 April 2017; Revision Accepted 2 August 2017)

\begin{abstract}
The importance of aeromagnetic as a basin depth discriminating tool is the emphasis in this study. Eight sheets of aeromagnetic total field intensity maps on a scale of 1:100,000 were analysed and the depth to magnetic basement compared with available drilled well data. The data was processed, filtered and transformed to other grids using either Oasis Montaj and USGS potential field software with their associated extension packages. Anomaly Separation, Spectral Analysis, Euler Deconvolution, Horizontal Gradient Magnitude were done using Oasis montaj and U.S.G.S softwares. The results of spectral analysis, Euler Deconvolution and horizontal gradient depth maps generated clearly indicates that the well bottom (well B) depth of $3.234 \mathrm{~km}$ compared with the different thematic magnetic basement depth from spectral $4.2 \mathrm{~km}$, Euler $6.421 \mathrm{~km}$, and HGM $4.0 \mathrm{kmis}$ effective in basement depth discrimination. The result show a unique closeness when compared between already drilled depth with interpreted magnetic depth results. This indicate that the method can be reliable as a basin depth determining tool in virgin sedimentary basins prior to seismic explorations.
\end{abstract}

KEYWORDS: Aeromagnetic, Euler Deconvolution, Spectral analysis, Horizontal gradient magnitude, Exploration.

\section{INTRODUCTION}

The study area is mainly onshore central Niger Delta with the south western end offshore. It is bounded within the geo-referenced location of Latitude $5^{0} 0^{1} 00^{11}$ $6^{0} 0^{1} 00^{11} \mathrm{~N}$ (north of the Equator) and Longitude $5^{0} 0^{1} 00^{\prime \prime}$ $7^{0} 0^{\prime} 00^{\prime \prime} \mathrm{E}$ (east of the Greenwich Meridian). It is drained by several distributaries southward into the Atlantic Ocean. States within the study area include Ondo, Edo, Delta, Bayelsa, Rivers, Imo and Anambra States, as shown in figure 1.Aeromagnetic data is known for determining depth to magnetic basement mostly in virgin areas. However, the present study is done in an already known highly explored basin using seismic and drilled oil well known in different locations. So, this work is meant to compare the depths derived from known oil wells location with those of different magnetic depth to basement techniques and the degree of accuracy of the method will serve as a guide for reliable usage in virgin areas where seismic methods are not available.

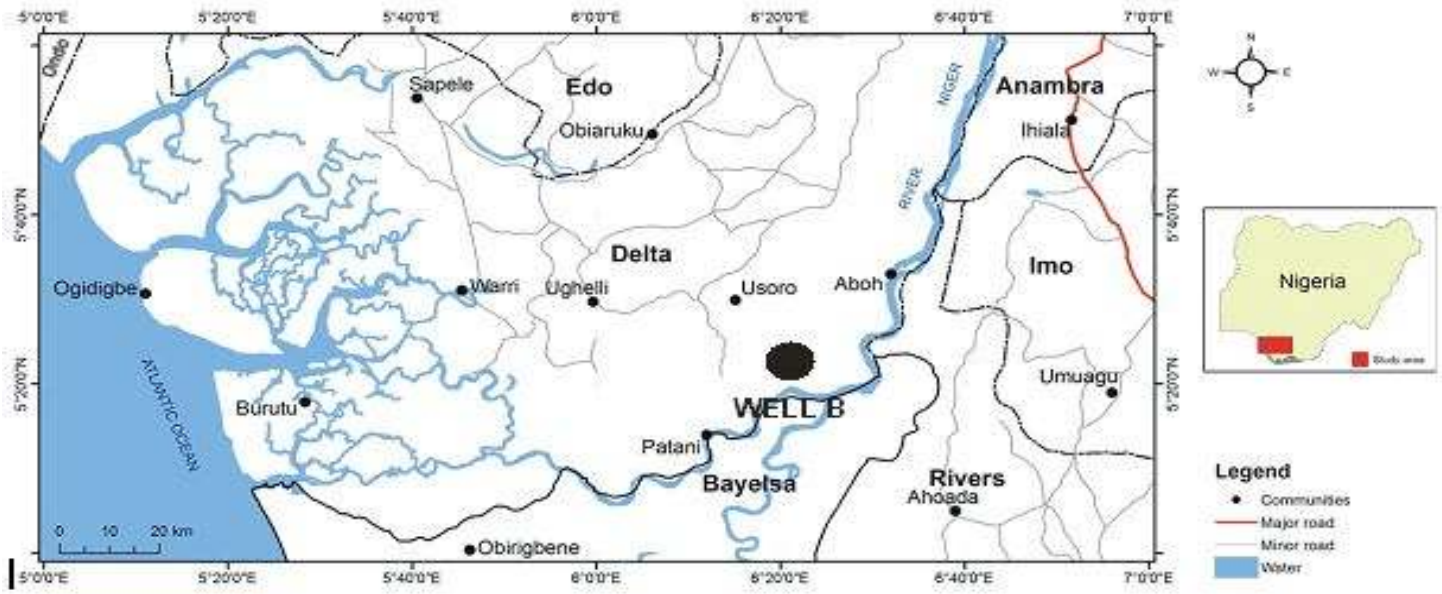

Fig.1: Location map of the study area.

D. A. Obi, Department of Geology, University of Calabar, Calabar, Cross River State, Nigeria.

S. E. Lebo, Department of Geology, University of Calabar, Calabar, Cross River State, Nigeria. 


\section{Geology of the study area}

The Study area is within the present day Niger Delta which is genetically related to the Benue Trough in terms of its evolution. The Niger Delta have tertiary sedimentary deposits of about 12,000 meters in thickness with three major lithostratigraphic units, the Akata Formation which is the bottom unit consist of thick marine Shales followed by Agbada Formation which is an alternation of Sandstones and Shales units in almost equal proportions (Petters 1991, Reijers 1996,
Whiteman 1982,). The Agbada Formation is overlain by the topmost Benin Formation consisting of mainly Sandstones and Alluvium deposits. However, the geologic map reveals the Ameke group (Eocene) as the oldest consisting of Sandstones with minor Shale's intercalations (Fig.2). This unit is overlain by the Ogwashi - Asaba Formation (Oligocene - Miocene) with Deltaic plain Sandstones and Mudswamps, this unit has several alternations that formed the successive overlain deposits to the topmost recent alluvium deposits.

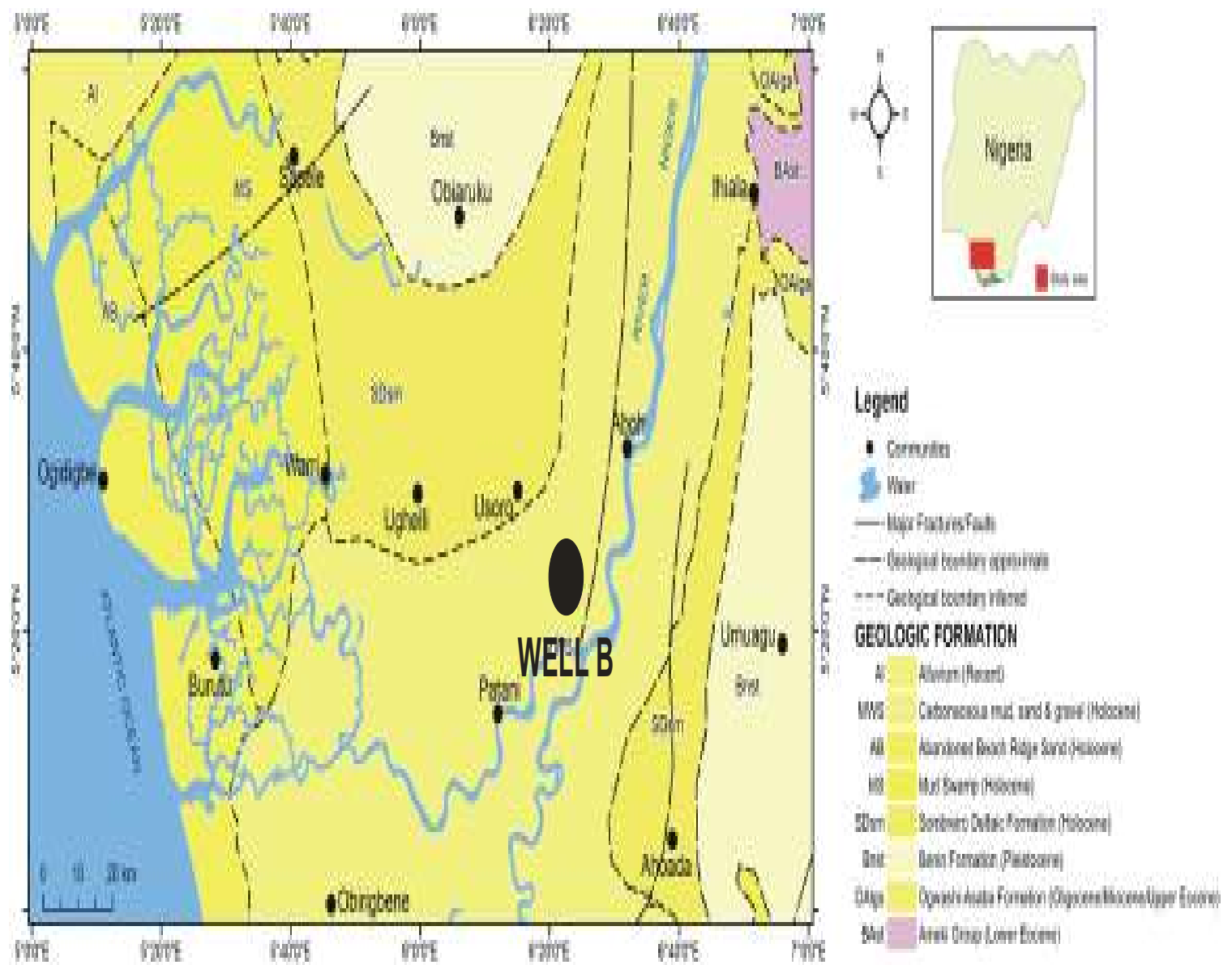

Figure 2: Geologic map of the study area.

\section{Data analysis / Results}

The materials used in this study include the following: (i) Eight sheets of aeromagnetic total intensity field maps $\left(0.5^{\circ} \times \quad 0.5^{\circ}\right)$ and high resolution aeromagnetic softcopy data covering the area.(ii) Well data with geo-referenced location of $6.603571 \mathrm{E}\left(6^{\circ} 36^{1}\right.$ $\left.21^{\prime \prime} \mathrm{E}\right)$ and latitude $5.49807 \mathrm{~N}\left(5^{\circ} 30^{\prime} 00^{\prime \prime} \mathrm{N}\right)$. (iii) Interactive Petrophysics and arc- GIS software.(iv) Oasis Montaj and U.S.G.S potential field software's (v) Surfer 9.0 software

The hard copy aeromagnetic data have a terrain clearance of $762 \mathrm{~m}$ above sea level, flight line spacing of $2000 \mathrm{~m}$, flight line orientation $020^{\circ} / 200^{\circ} \mathrm{NE}-\mathrm{SW}$, tie line spacing of $20,000 \mathrm{~m}$, and tie line orientation $110^{\circ} / 290^{\circ} \mathrm{NW}$. The softcopy high resolution aeromagnetic data has a terrain clearance of $80 \mathrm{~m}$ above sea level, flight line spacing of $500 \mathrm{~m}$, flight line orientation in the NW - SE direction, tie line spacing of
$2000 \mathrm{~m}$ and tie line orientation in the NE - SW direction. The data was acquired from Nigerian geological survey agency. A well data titled well B was obtained from Agip Oil Company and was used as a control during the data analysis. It has a well coordinate is $6.603571 \mathrm{E}\left(6^{\circ} 36^{\prime}\right.$ $\left.21^{\prime \prime} \mathrm{E}\right)$ and latitude $5.49807 \mathrm{~N}\left(5^{\circ} 30^{\prime} 00^{\prime \prime} \mathrm{N}\right)$, well Top is $1295.1028 \mathrm{~m}$, well Bottom is $3234.0000 \mathrm{~m}$, well depth is (3234.0000 - 1295.1028) 1938.8972m and has log suites of gamma ray log (GR), acoustic travel time log (DT), resistivity induction deep log (ILD), neutron porosity log (NPHI) and bulk density log (RHOB) which run from top to bottom.

Aeromagnetic maps were digitized manually and data processed using MS-DOS program in XYZ format which is the accepted by the USGS subroutine software programs referred to as PF (version 2.2) for potential fields. Gridding and map merging was done using ADDGRD, P2GRD, and JMERGER software's (Philips, 1997). 
Reduction to the pole was done using FFTFIL and R TP softwares while anomally separation was done using power spectrum SURFIT software for polynomial fitting techniques(Sheriff, 1991, Reeves 2005) in separating regional and residual fields. Results generated are presented in figure $3,4,5,6,7$ and table 1.0 and 2.0 . These results are similar to those obtained by other workers in similar areas. (Ofoegbu and Onuoha, 1992; Spector and Grant, 1970; Ferdi et al., 1997; Cordell and Grauch, 1985 Obi et al. 2008).

Euler Deconvolution depth analysis was done with the Geosoft Oasis Montaj software based on the work by Mushayandebvu et al. (2001) and result presented in figure 9.0

Horizontal Gradient Magnitude Depth Analysis was done using the USGS potential field software version 2.2 and result presented in figures 10, 11, and 12. The horizontal gradient method is a simple approach to estimating contact locations and depth (Blackely and Simpson, 1986, Philips 1997, Roeset et al., 1992).
In all computer depth estimation techniques, horizontal gradient magnitude (HGM) has the greatest number of assumptions about the sources (Philips, 1997). It is the least susceptible to noise in data because it only involves calculation of the two first-order horizontal derivative of the magnetic field.

Well log estimates/lithostratigraphy.

Lithostraitigraphic chat of well B was prepared using interactive petrophysical software and result presented in figure 13. Three log suites are plotted as gamma ray $\log (\mathrm{GR})$, neutron $\log (\mathrm{NPHI})$ and density $\log (\mathrm{RHOB})$ however, only the gamma ray log was used in this analysis for lithostratigraphic interpretations. (Asquith and Gibson, 1982, North 1985).Basically, was used in identifying sands and shales units to depths of $3200 \mathrm{~m}$, these depth point was posted to the various depth maps generated for correlation of subsurface depth estimates

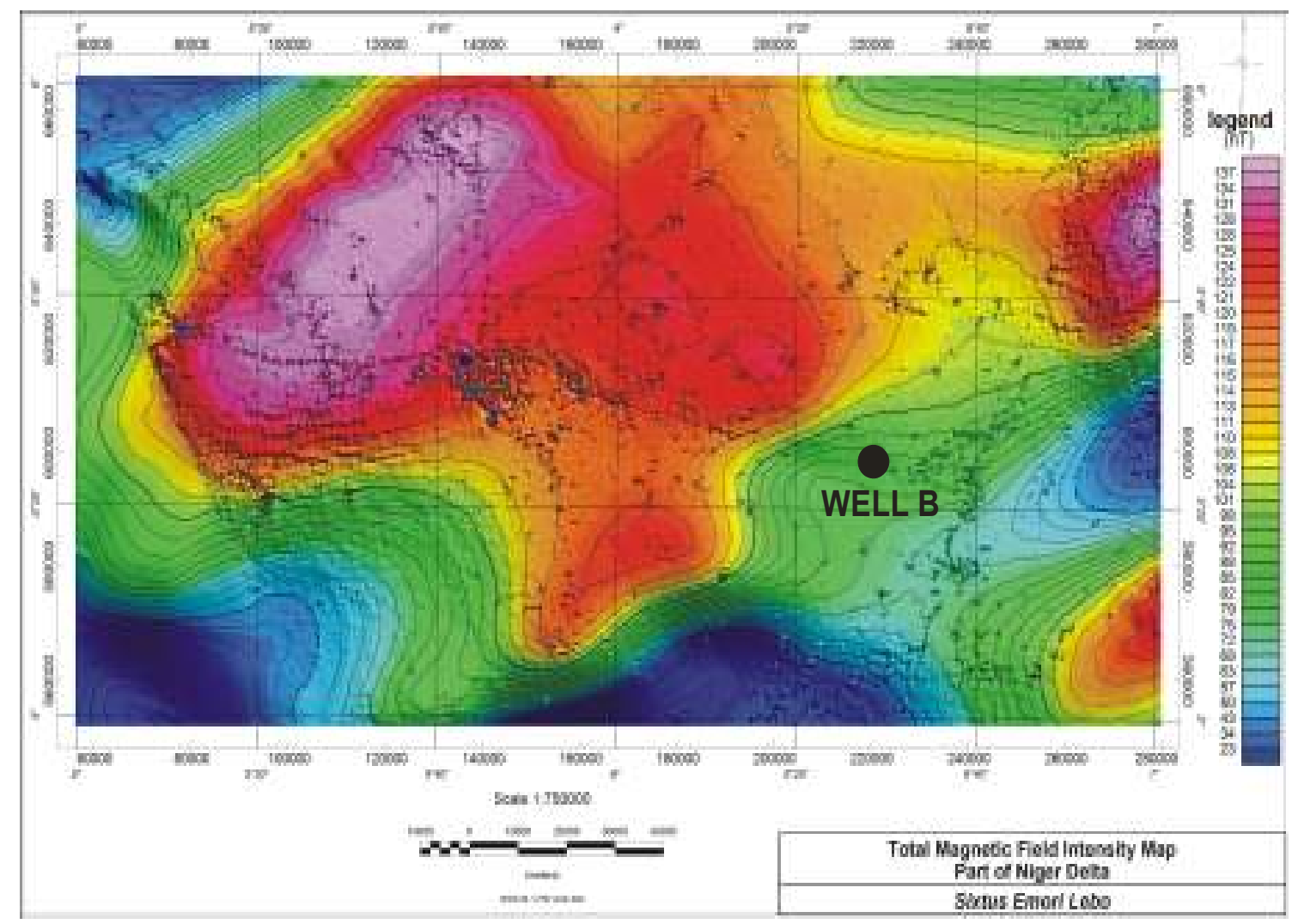

Fig. 3: Coloured High Resolution Total magnetic field intensity map of the study area (Field values are relative to a $32,000 \gamma$ base). 


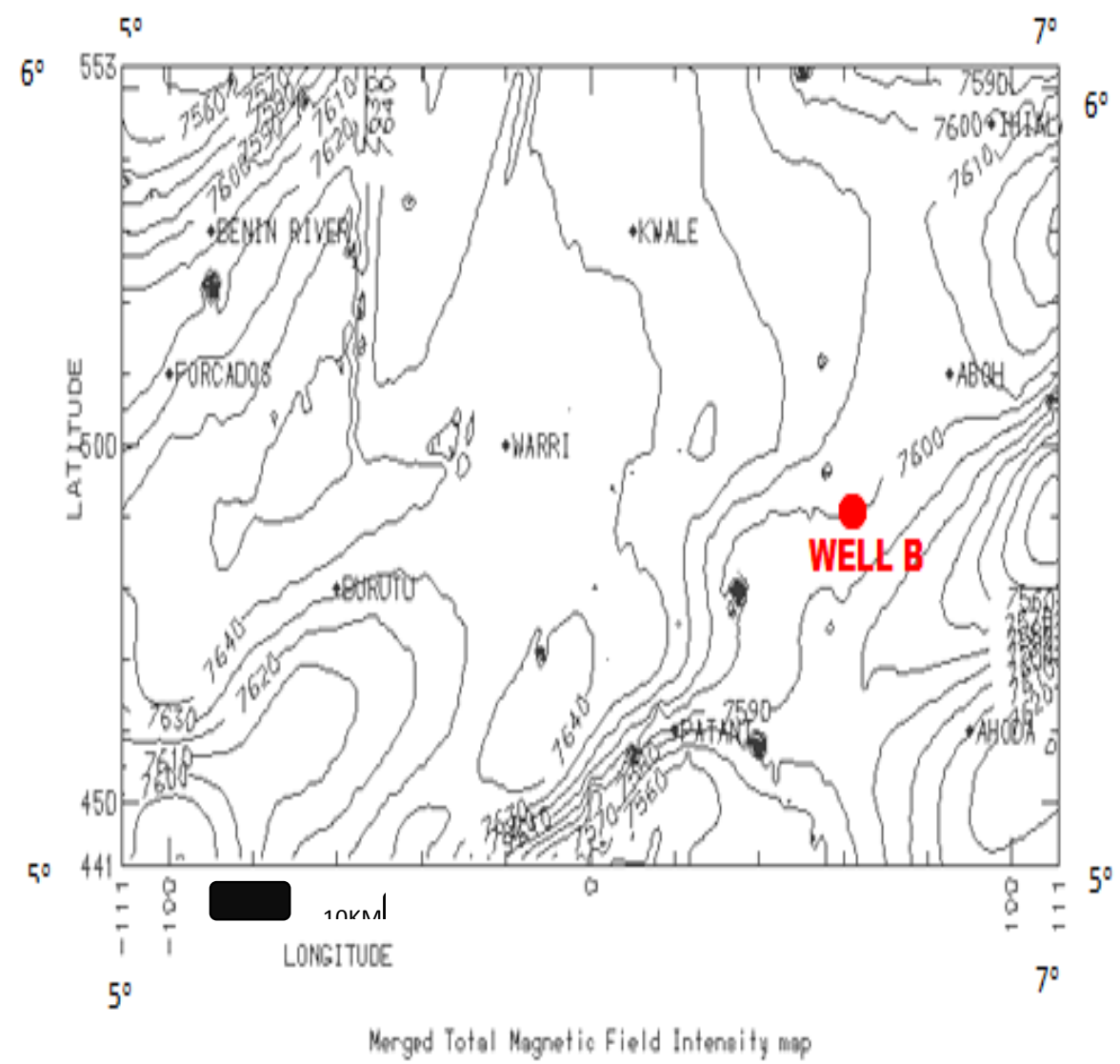

Fig. 4: Digitized Merged Total Magnetic Field Intensity of the Study area \{Field values are relative to a $25,000 \gamma$ (Contoured at 10nT interval)\}.

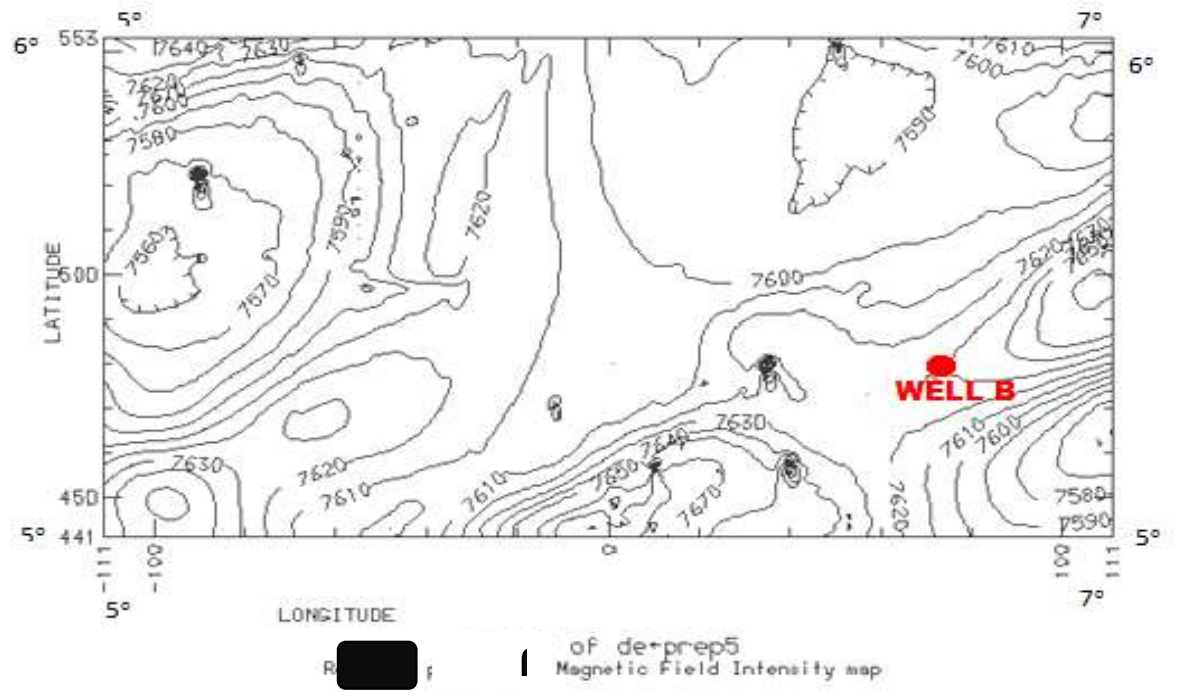

Fig. 5: Reduced to Pole Total Magnetic Field Intensity Map of the Study Area \{field values relative to a 25,000 $\gamma$ base (Contoured at 10nT interval). 


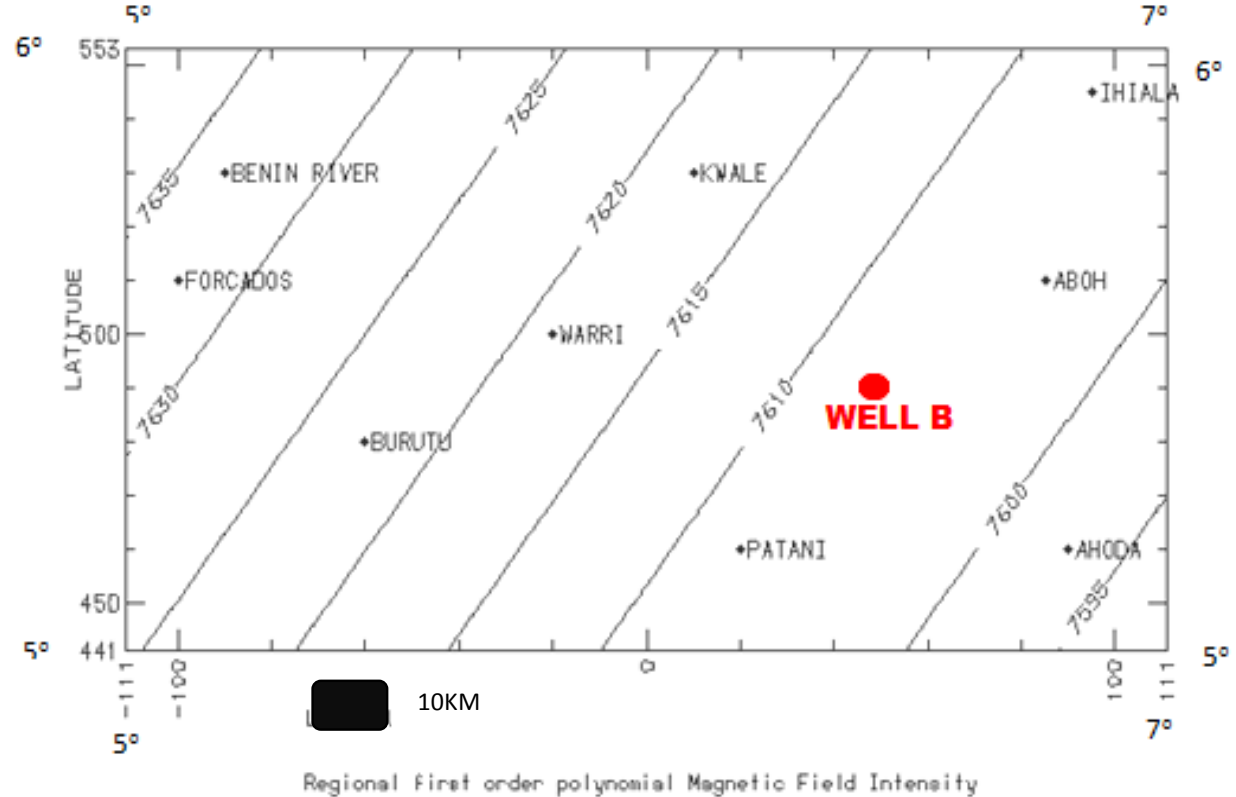

Fig. 6: Regional First Order Polynomial Magnetic Field Intensity of the Study Area ffield values relative to a $25,000 \gamma$ base (Contoured at 5nT interval)

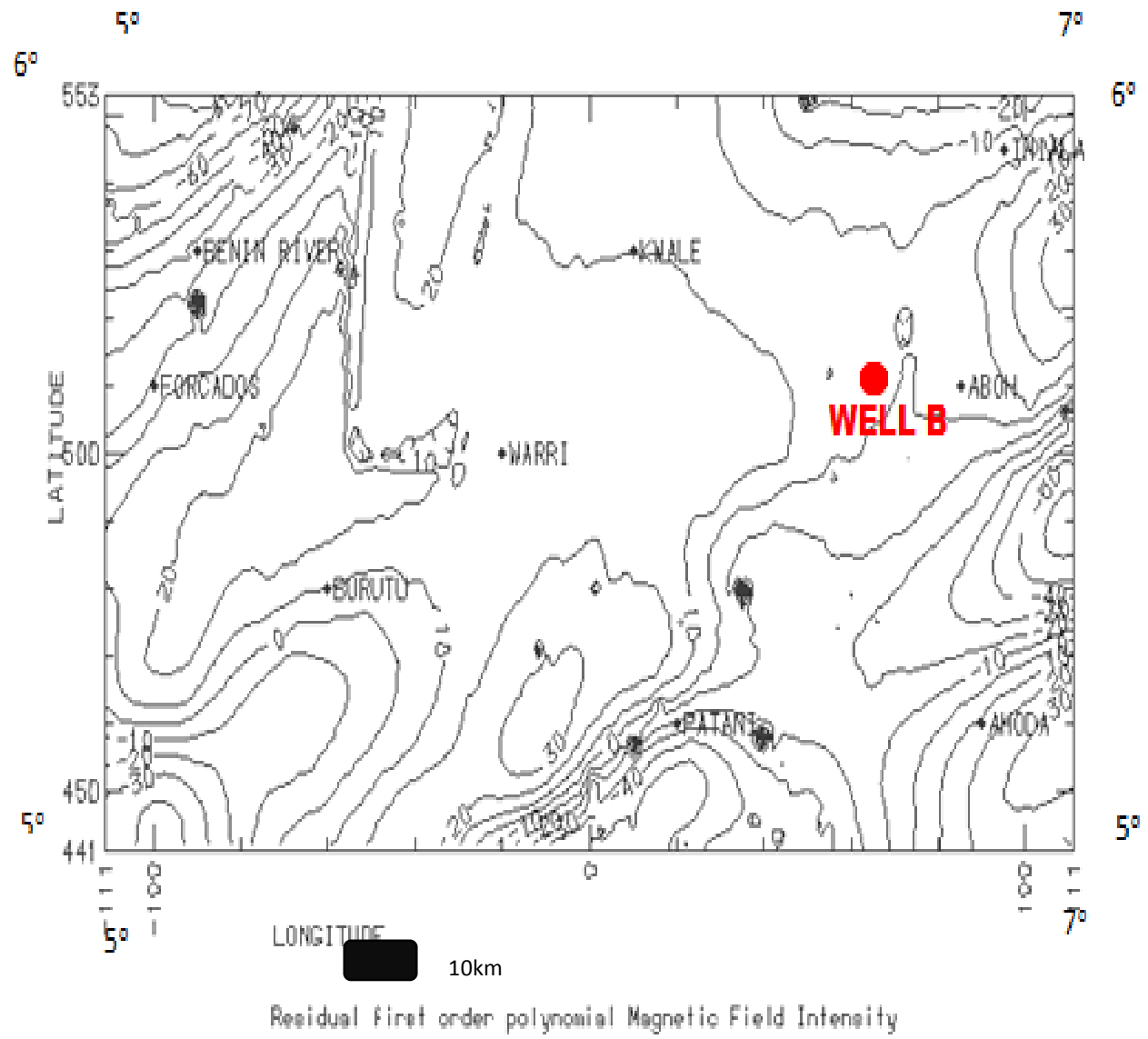

Fig. 7: Residual Polynomial Magnetic Field Intensity Map of the Study Area (Contoured at 10nT interval) 


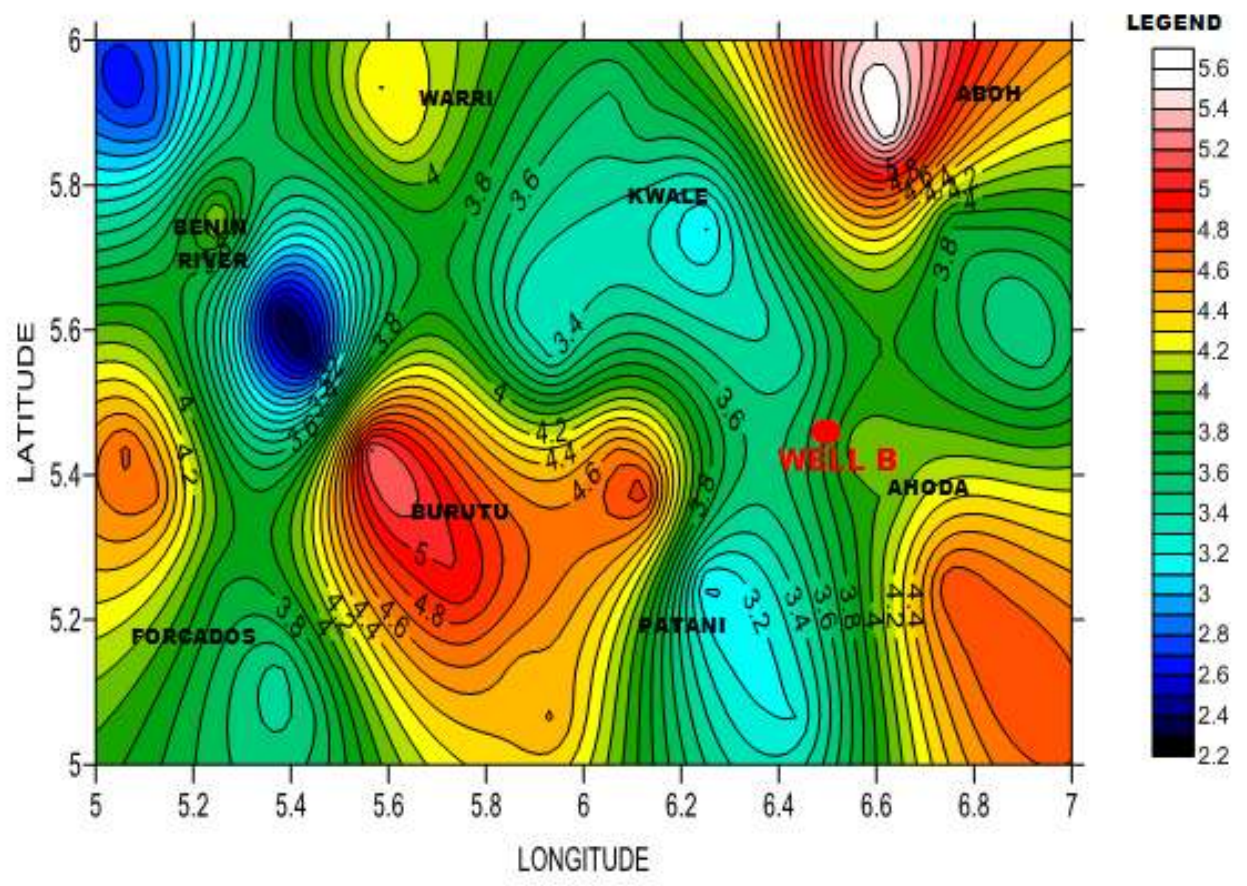

Fig. 8: Spectral depth map of the study area (Contoured at $0.1 \mathrm{~km}$ interval).

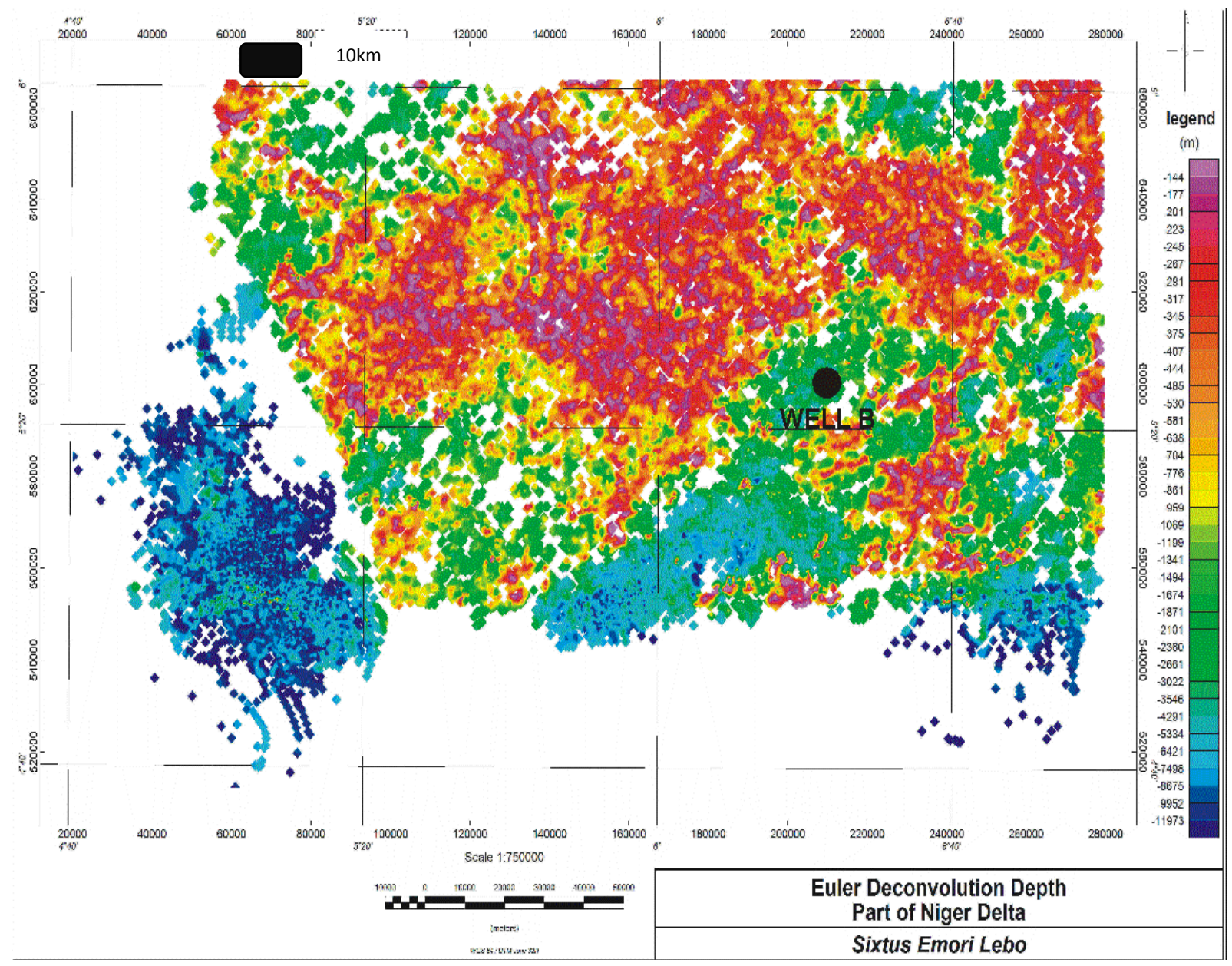

Fig. 9: Euler Deconvolution depth map of the study area. 


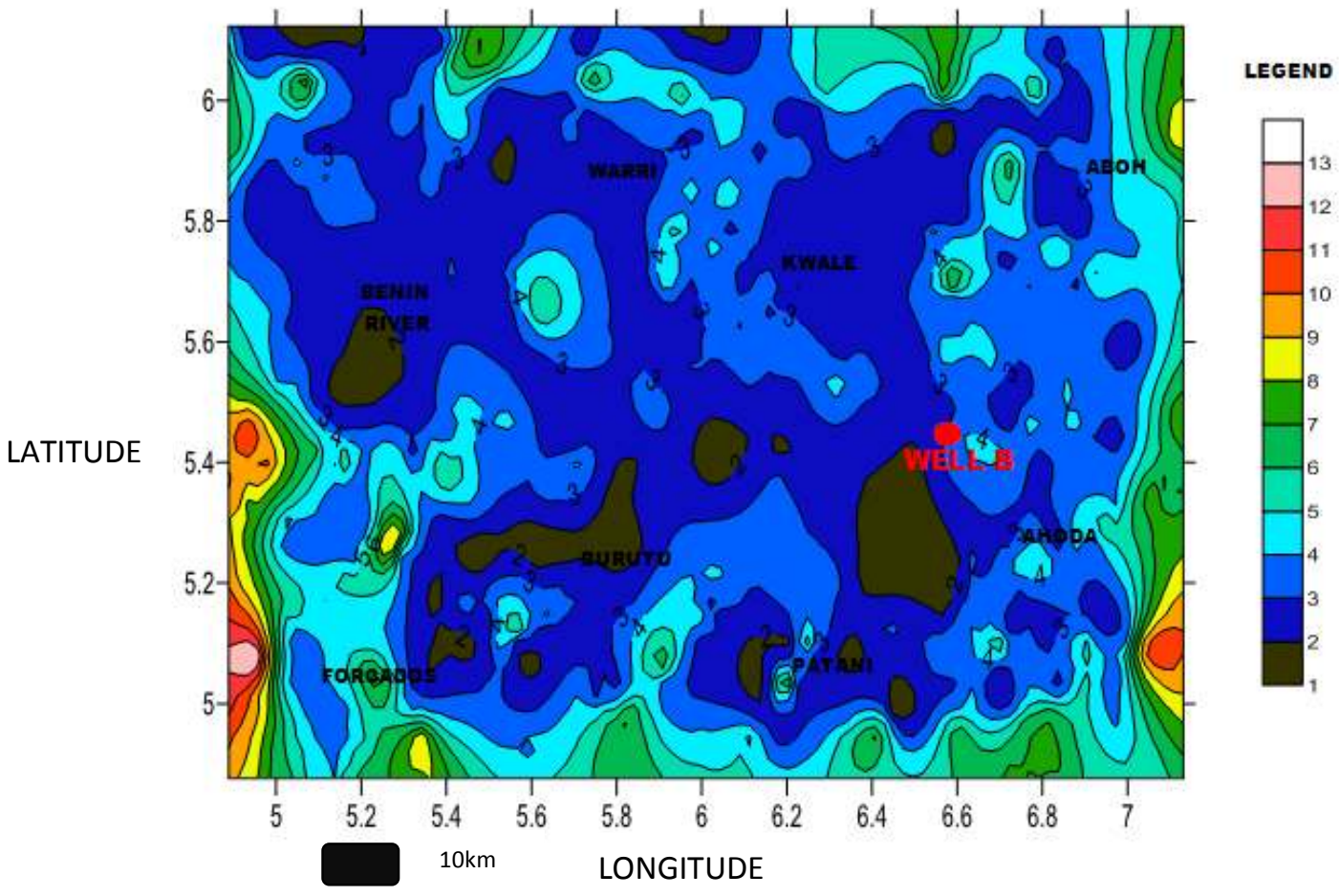

Fig. 10: Horizontal gradient magnitude depth map of the study area (Contoured at $1 \mathrm{~km}$ interval)

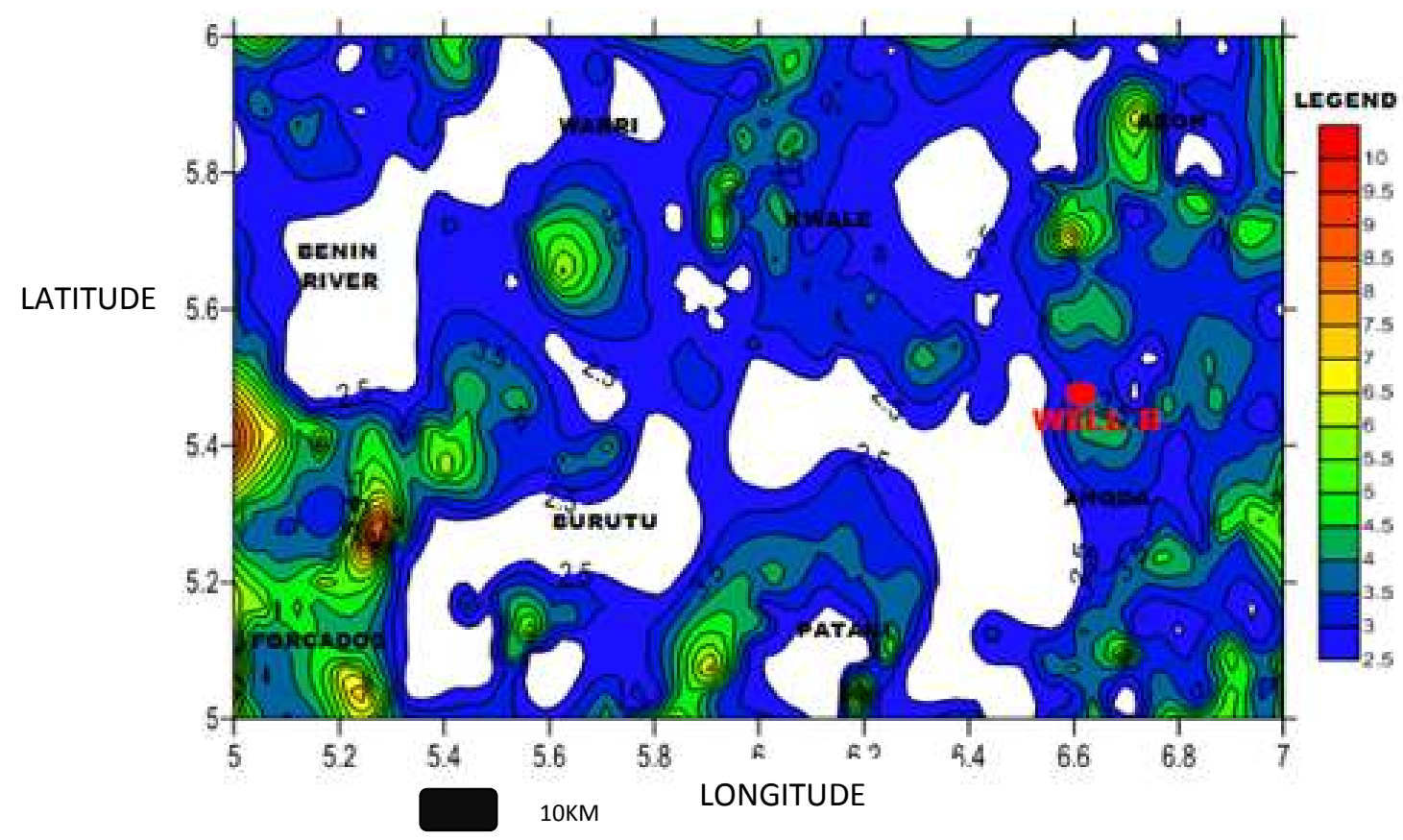

Fig. 11: Horizontal gradient magnitude depth map of the study area discriminating from $2.5 \mathrm{~km}$ (Contoured at $0.5 \mathrm{~km}$ interval). 


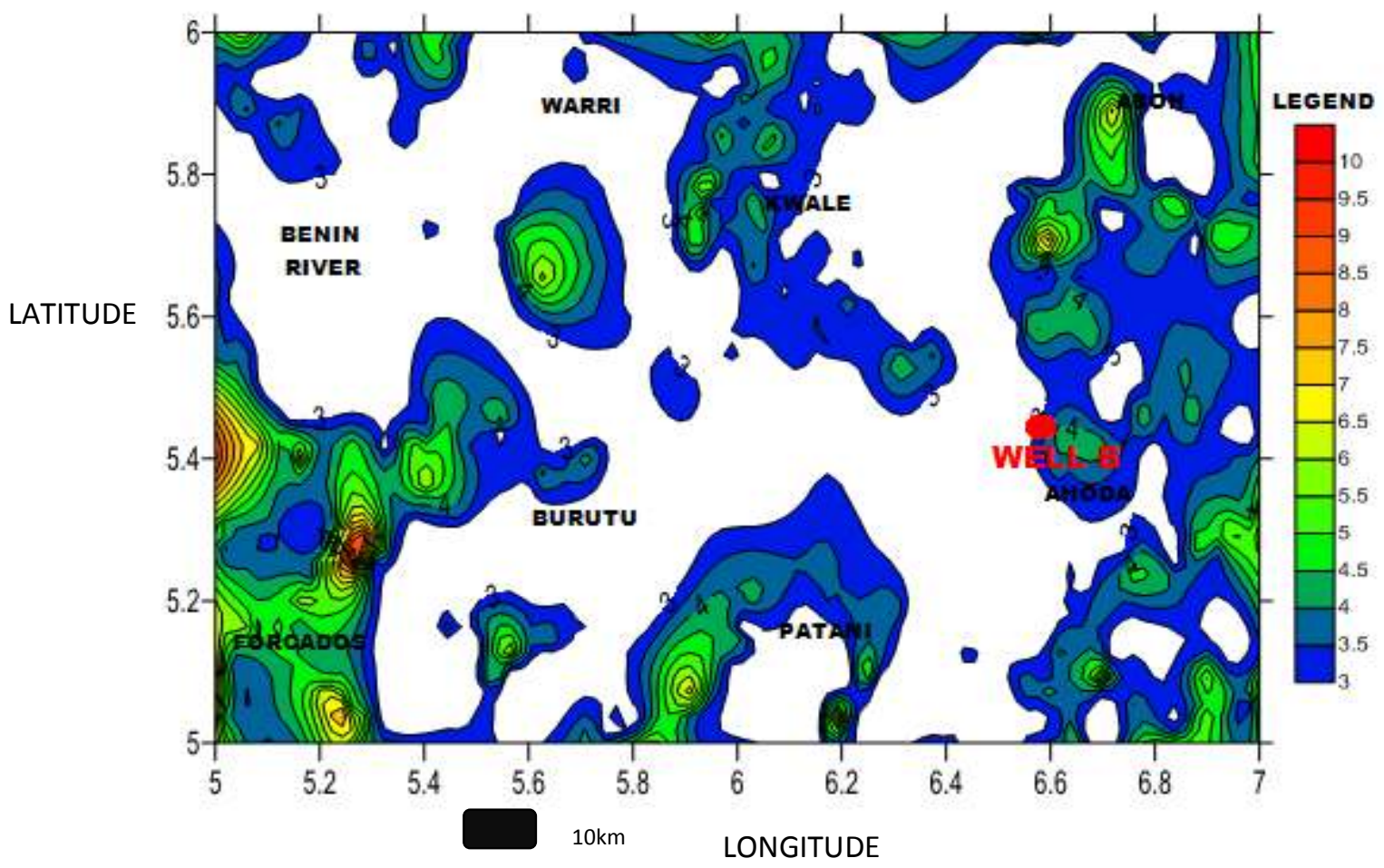

Fig.12. Horizontal gradient magnitude depth map of study area discriminating of sediment thickness $3.0 \mathrm{~km}$ (Contoured at $0.5 \mathrm{~km}$ )

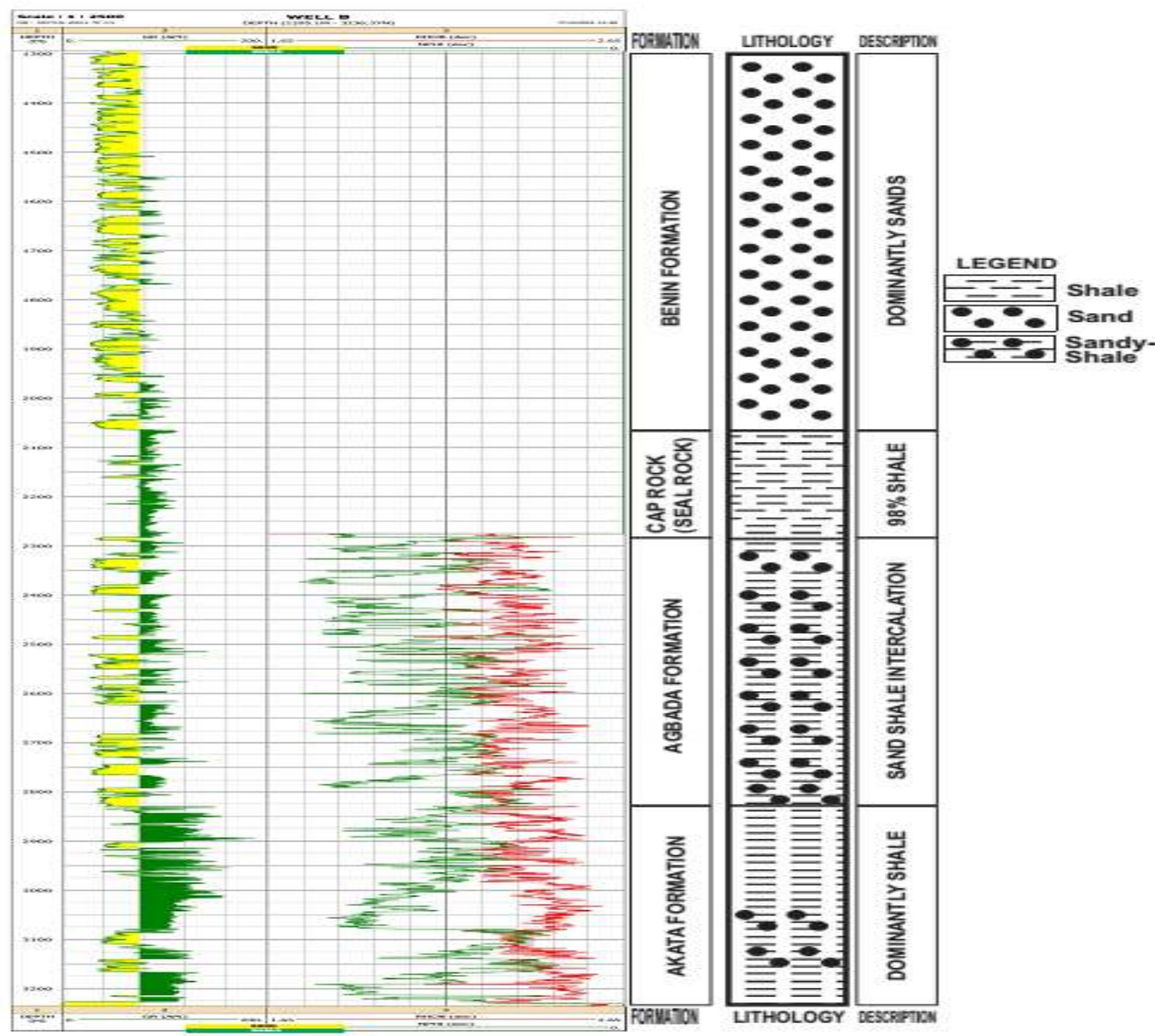


Table 1:

Table of different depth comparism within the well in the study area

\begin{tabular}{lll}
\hline S/N & Depth type & Depth value $(\mathrm{Km})$ \\
\hline 1 & Spectral depth & 4.2 \\
2 & Euler depth & 7.498 \\
3 & HGM depth & 4.0 \\
4 & Well depth & 3.234 \\
\hline
\end{tabular}

Table 2: Spectral depth of some part of the Niger Delta

\begin{tabular}{|c|c|c|c|c|c|c|c|c|c|c|}
\hline $\mathrm{S} / \mathrm{N}$ & MAP & $\begin{array}{l}\mathrm{D}-1 \\
(\mathrm{KM})\end{array}$ & $\begin{array}{l}\mathrm{D}-2 \\
(\mathrm{KM})\end{array}$ & $\begin{array}{l}\text { D-3 } \\
\text { (KM }\end{array}$ & $A-1$ & A-2 & A-3 & $x$ & $\mathrm{Y}$ & DEPTH \\
\hline 1 & $\begin{array}{l}\text { BENIN } \\
\text { RIVER } 1\end{array}$ & 1.0660 & 4.1670 & 16.2500 & 0.1054 & 0.6065 & 12.8000 & 5.2500 & 5.7500 & 4.17 \\
\hline 2 & $\begin{array}{l}\text { BENIN } \\
\text { RIVER } 2\end{array}$ & 0.8079 & 2.8400 & 12.5000 & 0.1520 & 0.6065 & 11.4000 & 5.1250 & 5.8750 & 2.84 \\
\hline 3 & $\begin{array}{l}\text { BENIN } \\
\text { RIVER } 3\end{array}$ & 0.9231 & 2.3080 & 8.6670 & 0.8208 & 12.1800 & 12.1400 & 5.3750 & 5.6250 & 2.31 \\
\hline 4 & $\begin{array}{l}\text { BENIN } \\
\text { RIVER } 4\end{array}$ & 0.8217 & 2.6000 & 11.5000 & 0.1440 & 0.6065 & 10.7400 & 5.0625 & 5.9375 & 2.60 \\
\hline 5 & $\begin{array}{l}\text { BENIN } \\
\text { RIVER } 5\end{array}$ & 0.9321 & 2.3380 & 8.4500 & 0.8210 & 11.9000 & 10.6800 & 5.4375 & 5.5625 & 2.34 \\
\hline 6 & $\begin{array}{l}\text { FORCADOS } \\
1\end{array}$ & 0.7160 & 3.8200 & 9.6880 & 0.0249 & 0.3172 & 4.4820 & 5.2500 & 5.2500 & 3.82 \\
\hline 7 & $\begin{array}{l}\text { FORCADOS } \\
2\end{array}$ & 0.9708 & .6430 & 0.2600 & 0153 & 3679 & 7.3890 & 1250 & .3750 & 4.64 \\
\hline 8 & $\begin{array}{l}\text { FORCADOS } \\
3\end{array}$ & 1.8330 & 3.4480 & 7.9400 & 0.8200 & 0.6065 & 12.1800 & 5.3750 & 5.1250 & 3.45 \\
\hline 9 & $\begin{array}{l}\text { FORCADOS } \\
4\end{array}$ & 3 & 0 & 0 & 3 & 10 & 30 & 25 & 75 & .72 \\
\hline 10 & $\begin{array}{l}\text { FORCADOS } \\
5\end{array}$ & 1.7420 & 3.5500 & 8.2000 & 0.8405 & 0.3544 & 6.3210 & 5.4375 & 5.0625 & 3.55 \\
\hline 11 & WARRI 1 & & 3.8200 & 11.7900 & 0247 & 0.3172 & 7.3890 & & 500 & 3.82 \\
\hline 12 & WARRI 2 & 1.1140 & 4.2800 & 10.6300 & 0.0673 & 0.3670 & 4.4820 & 5.6250 & 5.8750 & 4.28 \\
\hline 13 & WARRI 3 & 0.8754 & 3.3400 & 8.0560 & 0.1111 & 1.6490 & 12.180 & 5.8750 & 5.6250 & 3.34 \\
\hline 14 & WARRI 4 & 1.0150 & 4.3000 & 10.5400 & 0.0672 & 0.4250 & 4.3820 & 5.5625 & 5.9375 & 4.30 \\
\hline 15 & WARRI 5 & 0.9241 & 3.3800 & 8.2000 & 0.1141 & 1.5490 & 11.9200 & 5.9375 & 5.5625 & 3.38 \\
\hline 16 & BURUTU 1 & 0.9677 & 5.0000 & 9.1670 & 0.0673 & 0.6065 & 4.4820 & 5.7500 & 5.2500 & 5.00 \\
\hline 17 & BURUTU 2 & 1.1940 & 5.1790 & 11.0700 & 0.0638 & 2.7180 & 4.4820 & 5.6250 & 5.3750 & 5.18 \\
\hline 18 & BURUTU 3 & & 4.4230 & 13.6400 & 0.1111 & 1.0000 & 20.0900 & 5.8750 & 5.1250 & 4.42 \\
\hline 19 & BURUTU 4 & 00 & 5.2100 & 12.0400 & 0.0652 & 2.6080 & 5.1250 & 5.5625 & 5.4375 & 5.21 \\
\hline 20 & BURUTU 5 & 1.0250 & 4.5200 & 13.5000 & 0.1340 & 1.1000 & 22.0500 & 5.9375 & 5.0625 & 4.52 \\
\hline 21 & KWALE 1 & 1.194 & 3.065 & 13.0 & 0.0302 & 0.3679 & 7.389 & 6.2500 & 5.7500 & 3.07 \\
\hline 22 & KWALE 2 & 0.4775 & 3.650 & 10.90 & 0.0067 & 0.06066 & 12.18 & 6.1250 & 5.8750 & 3.65 \\
\hline 23 & KWALE 3 & 1.401 & 3.387 & 10.38 & 0.0820 & 0.3679 & 4.482 & 6.3750 & 5.6250 & 3.39 \\
\hline 24 & KWALE 4 & 20 & 3.602 & 60 & 64 & 65 & 13.20 & 625 & 375 & 3.60 \\
\hline 25 & KWALE 5 & 1.440 & 3.450 & 10.50 & 0.0835 & 0.6666 & 4.220 & 6.4375 & 5.5625 & 3.45 \\
\hline 26 & PATANI 1 & 0.7162 & 3.065 & 14.55 & 0.0208 & 2.7180 & 90.02 & 6.2500 & 5.2500 & 3.07 \\
\hline 27 & PATANI 2 & 0.8276 & 4.88 & 13.30 & 0.8208 & 4.482 & 90.02 & 6.1250 & 5.3750 & 4.88 \\
\hline 28 & PATANI 3 & 1.114 & 3.167 & 13.50 & 0.1353 & 1.6490 & 20.09 & 6.3750 & 5.1250 & 3.17 \\
\hline 29 & PATA & 0.7520 & 4.60 & 12.82 & 0.8102 & 4.320 & 91.01 & 6.0625 & 5.4375 & 4.60 \\
\hline 30 & PAT & & 3.20 & 13.20 & 0.6320 & 1.550 & 21.18 & 6.4375 & 5.0625 & 3.20 \\
\hline 31 & $\mathrm{ABOH} 1$ & 0.6 & 3.820 & 12.14 & 0.0024 & 0.2231 & 12.18 & 6.7500 & 5.7500 & 3.82 \\
\hline 32 & $\mathrm{ABOH} 2$ & 1.290 & 5.62 & 12.50 & 0.0024 & 0.6065 & 12.18 & 6.6250 & 5.8750 & 5.62 \\
\hline 33 & $\mathrm{ABOH} 3$ & 0.9549 & 3.50 & 11.43 & 0.0142 & 0.3679 & 7.389 & 6.8750 & 5.6250 & 3.50 \\
\hline 34 & $\mathrm{ABOH} 4$ & 1.250 & 5.50 & 12.30 & 0.2453 & 0.6162 & 12.25 & 6.5625 & 5.9375 & 5.50 \\
\hline 35 & $\mathrm{ABOH} 5$ & 0.8540 & 3.55 & 11.20 & 0.0135 & 0.3240 & 7.214 & 6.9375 & 5.5625 & 3.55 \\
\hline 36 & AHODA 1 & 0.9708 & 4.80 & 12.50 & 0.1111 & 0.718 & 90.02 & 6.7500 & 5.2500 & 4.80 \\
\hline 37 & AHODA 2 & & 4.00 & 11.79 & 0.8200 & 4.482 & 148.4 & 6.6250 & 5.3750 & 4.00 \\
\hline 38 & AHODA 3 & 1.607 & 4.8 & 13.75 & 0.6065 & 54.600 & 1097 & 6.8750 & 5.1250 & 4.80 \\
\hline 39 & AHODA 4 & 1.125 & 4.100 & 11.75 & 0.8200 & 4.4180 & 145.2 & 6.5625 & 5.4375 & 4.10 \\
\hline 40 & AHODA 5 & 1.625 & 4.780 & 12.70 & 0.6365 & 48.500 & 1058 & 6.9375 & 5.0625 & 4.78 \\
\hline
\end{tabular}




\section{DISCUSSION / CONCLUSION}

The availability of drilled well data within the basin makes it easier for the thematic magnetic depth estimates generated be correlated or tied at the well as shown in table 1 . There are no wells drilled to basement within the study area, so the available drilled well B, was used for correlation purposes. The reduction to pole map (fig. 5) show well centered anomalies with well defined outlines which were not well displayed in the observed total magnetic field intensity map (fig.4). The regional field map (fig.7) indicate a North-East to SouthWest orientation of the regional magnetic field, this trending is same as the regional trends of the Benue Trough. The residual polynomial magnetic field map (fig.8) have eight prominent anomalies where three of the anomalies are deep seated along Burutu, Benin River, and Warri and the other five anomalies are Shallow seated along Patti, Ahoda, and Aboh. The deep seated anomalies are recognised by widely spaced contours while closely space small and rounded contours represent Shallow seated basement rocks, which also represents areas of thin sedentary rocks deposits.

The Spectral depth map of the area (fig.9) indicate a progressive increament of basin thickness from Patani $(3.2 \mathrm{~km})$ towards Ahoda $(4.4 \mathrm{~km})$ and also progress by increasing in depths towards Burutu $(5.2 \mathrm{~km})$, and begin to shallow out towards Kwale (3.6 $\mathrm{km})$, Benin River $(3.0 \mathrm{~km})$. The results reveals areas with greater sediment accumulation which could serve as better exploration targets. Also, Euler Deconvolution depth map (fig.10) indicate a progressive increament in sediment accumulation from Ahoda towards Burutu and Forcados reaching depths of $12.0 \mathrm{~km}$. The Horizontal Gradient Magnitude depths maps (figs. 11, 12, 13) show subsurface depth variations contoured at different contouring intervals which discriminates areas of different sedimentary depth thickness $3.0 \mathrm{~km}$ and above (fig.13) which are found in large portions around Forcados towards Burutu .

From the result generated using the interactive petrophysical software (IP) as shown in figure 13, different formations were identified and interpreted based on approximate depth intervals associated with them. The well has a well top of $1295.1028 \mathrm{~m}$, well bottom of $3234.00 \mathrm{~m}$ and well interval of $(3234.00$ $1295.1028)=1938.8972 \mathrm{~m}$. Depth interval of 1295.1028 - $1965.0000 m$ (669.8972m) is made up of dominantly sand and it is interpreted as the Benin Sand Formation. Interval of $1965.0000-2285.0000 \mathrm{~m}$ (320.0000m) is made up of mainly shale and interpreted as cap rock (seal rock), while 2285.0000 - 2825.0000m $(540.0000 \mathrm{~m})$ is made up of intercalations of sand and shale and it is interpreted as Agbada Formation. The last interpreted formation starts from $2825.0000 \mathrm{~m}$ $3234.0000 \mathrm{~m}(409.0000 \mathrm{~m})$. It is dominantly shale and it is interpreted as Akata Formation.

Computed depth to the top of magnetic basement within the well area is as follows:

Spectral Depth estimate is $4.2 \mathrm{~km}$, Euler depth estimate is $7.498 \mathrm{~km}$ and Horizontal Gradient Magnitude depth is $4.0 \mathrm{~km}$ and the well depth is $3.234 \mathrm{~km}$ as shown in table 1. From the above correlation, the magnetic basement depth estimates are greater than the drilled depth, which makes the result from magnetic analysis reliable. From the HGM depth discriminating maps, seismic exploration is most favourable in areas of sediment thickness above $2.5 \mathrm{~km}$ which coincide with the Forcados, Patani, Kwale, Ahoda and Aboh areas .

Conclusively, this method has demonstrated that depth to basement information obtained from magnetic analysis using the above depth discriminating techniques is reliable as a depth to basement investigating tool that could assist in planning seismic reflection explorations surveys in relatively unexplored basins.

\section{REFERENES}

Asquith, G. B. and Gibson, C. R., 1982. Basic well log analysis for geologist. American Association of Petroleum Geologist Methods in exploration, (3): $118-121$.

Benkhelil, J., 1989. The origin and evolution of the Cretaceous Benue Trough (Nigeria). Journal of African Earth Sciences, (8): 251 - 282.

Blakely, R. J and Sampson, R. W., 1986. Approximating edges of source bodies from gravity or magnetic anomalies. Geophysics, 51, (7): $1194-1498$.

Burke, K.; Dessauvagic, T. E., and Whiteman 1971. Opening of the Gulf of Guniea and Geological History of the Benue Deoression and the Niger Delta. Nature physical Sciences (233): 51-55.

Cordell, L. and Grauch, V. J. S., 1985. Mapping basement magnetization zones from aeromagnetic data in the San Juan Basin, New Mexico in Hinze, W.J.Ed., The utility of regional gravity and magnetic anomaly maps. Society of Exploration Geophysics, (18): 1 - 197.

Cratchley, C. R., Louis, P, and Ajakaiye, D. E., 1984. Geophysical and geological evidence for the Benue - Chad Basin Cretaceous rift valley system and its tectonic implications. Journal of African Earth Sciences, 2, (2): 141 -150.

Ferdi, M., Quarta, T and Santis, A., 1997. Inherent power-law behaviour of magnetic field power spectra from Spector and Grant ensemble. Journal of Geophysics, 62, (4): 1143 -1150.

Genik, G. J., 1992. Regional framework, structural and petroleum aspect of rift basins Niger, Chad and the Central African Republic (C.A.R.). Journal of Tectonophysics, 213, (1992): $168-185$.

Mascle, J. 1976. Submarine Niger Delta: structural framework. Nigerian Journal of Mining Geology, 13, (1): $12-28$.

Mushanyandevu, M. F., Driel, P. V., Reid, A. B., and Fairhead, J. D., 2001. Magnetic Source parameters of two-dimensional structures using extended Euler Deconvolution. Geophysics, 66, (3): 814823. 
North, F. K., 1985. Petroleum Geology. Boston, Unwen Hyman. 650.

Nwajide, C. S., 2013. Geology of Nigeria's Sedimentary Basins. CSS Bookshop limited. $131-182,277$ $-518$.

Peters, S. W., 1991. Regional Geology of Africa. Springer-Verlag Berlin Heidelberg, 594 - 612.

Philips, J. D., 1997. Potential Field Geophysical Software for the PC version 2.2. USGS open file report 97-725.

Obi , D. A. Okereke, C. S. Egeh, U. E. and Olagundo Ye, O.O. 2008. Aeromagnetic modeling in evalu Ting the hydrocarbon potential of the basement of the Calabar Flank. Journal of Mining and Geology (44): 151-160.

Ofoegbu, C. O and Onuoha, K. M., 1992. Analysis of magnetic data over the Abakaliki Anticlinorium of the lower Benue Trough, Nigeria. Marine and Petroleum Geology, (8): 174-181.

Reeves, C., 2005. Aeromagnetic Surveys Principles, Practice and Interpretation. Geosoft publishers.

Reijers, T. J. A., 1996. Selected Chapters on Geology. A case study of the Niger Delta. Shell Petroleum Development Company, 113-114.

Roset, W. R., Verhoef, J and Pilkington, M., 1992. Magnetic interpretation using the 3-D analytical Signal. Geophysics, (57): $116-125$.

Sherief, R. E., 1991. Encyclopaedic Dictionary of Exploration Geophysics 3rd Ed. Published by Society for Exploration Geophysicist.

Spector, A. E. and Grant, F.S., 1970. Statistical model for interpreting aeromagnetic data. Geophysics, (50): 1951 - 1960.

Whiteman, A. J., 1982. Nigeria: Its Petroleum Geology, Resources and Potentials, volume 1 \& 2. Graham and Trotman London, 110 - 163, 251 276.

Wright, J. B., Hasting, D.A., Jones, W. B. and Williams, H. R., 1985. Geology and Mineral Resources of West Africa. George Allen \& Unwin publishers Ltd. 98 $-112$. 